Geological Magazine

www.cambridge.org/geo

\section{Original Article}

Cite this article: Corradetti A, Spina V, Tavani S, Ringenbach JC, Sabbatino M, Razin P, Laurent O, Brichau S, and Mazzoli S (2020) Late-stage tectonic evolution of the Al-Hajar Mountains, Oman: new constraints from Palaeogene sedimentary units and lowtemperature thermochronometry. Geological Magazine 157: 1031-1044. https://doi.org/ $10.1017 /$ S0016756819001250

Received: 8 July 2019

Revised: 5 September 2019

Accepted: 15 September 2019

First published online: 12 December 2019

\section{Keywords:}

Oman FTB; Cenozoic deformation; remote sensing; thermochronology

\section{Author for correspondence:}

A Corradetti,

Email: amerigo.corradetti@qatar.tamu.edu

\title{
Late-stage tectonic evolution of the Al-Hajar Mountains, Oman: new constraints from Palaeogene sedimentary units and low-temperature thermochronometry
}

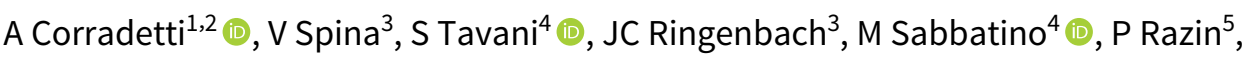 \\ O Laurent ${ }^{6}$, S Brichau ${ }^{7}$ and S Mazzoli ${ }^{1}$ (1)

\begin{abstract}
${ }^{1}$ School of Science and Technology, Geology Division, University of Camerino. Via Gentile III da Varano, 62032 Camerino (MC), Italy; ${ }^{2}$ Department of Petroleum Engineering, Texas A\&M University at Qatar, Doha, Qatar; ${ }^{3}$ Total E\&P, CSTJF, Avenue Larribau, 64000 Pau, France; ${ }^{4}$ DiSTAR, Università di Napoli Federico II, 21 Via vicinale cupa Cintia, 80126 Napoli, Italy; ${ }^{5}$ ENSEGID, Institut Polytechnique de Bordeaux, 1 allée Daguin, 33607 Pessac, France; ${ }^{6}$ Total E\&P, Paris, France and ${ }^{7}$ Géosciences Environnement Toulouse (GET), Université de Toulouse,
\end{abstract} \\ UPS, CNRS, IRD, CNES, 14 avenue E. Belin, 31400, Toulouse, France
}

\begin{abstract}
Mountain building in the Al-Hajar Mountains (NE Oman) occurred during two major shortening stages, related to the convergence between Africa-Arabia and Eurasia, separated by nearly $30 \mathrm{Ma}$ of tectonic quiescence. Most of the shortening was accommodated during the Late Cretaceous, when northward subduction of the Neo-Tethys Ocean was followed by the ophiolites obduction on top of the former Mesozoic margin. This shortening event lasted until the latest Santonian - early Campanian. Maastrichtian to Eocene carbonates unconformably overlie the eroded nappes and seal the Cretaceous foredeep. These neo-autochthonous post-nappe sedimentary rocks were deformed, along with the underlying Cretaceous tectonic pile, during the second shortening event, itself including two main exhumation stages. In this study we combine remotely sensed structural data, seismic interpretation, field-based structural investigations and apatite $(\mathrm{U}-\mathrm{Th}) / \mathrm{He}(\mathrm{AHe})$ cooling ages to obtain new insights into the Cenozoic deformation stage. Seismic interpretation indicates the occurrence of a late Eocene flexural basin, later deformed by an Oligocene thrusting event, during which the post-nappe succession and the underlying Cretaceous nappes of the internal foredeep were uplifted. This stage was followed by folding of the post-nappe succession during the Miocene. AHe data from detrital siliciclastic deposits in the frontal area of the mountain chain provide cooling ages spanning from 17.3 to $42 \mathrm{Ma}$, consistent with available data for the structural culminations of Oman. Our work points out how renewal of flexural subsidence in the foredeep and uplift of the mountain belt were coeval processes, followed by layer-parallel shortening preceding final fold amplification.
\end{abstract}

(c) The Author(s), 2019. Published by Cambridge University Press. This is an Open Access article, distributed under the terms of the Creative Commons Attribution licence (http:// creativecommons.org/licenses/by/4.0/), which permits unrestricted re-use, distribution, and reproduction in any medium, provided the original work is properly cited.

\section{CAMBRIDGE} UNIVERSITY PRESS

\section{Introduction}

The processes of progressive thrust propagation into the foreland basin and associated depocentre migration have been well known for decades (e.g. Lyon-Caen \& Molnar 1985; Homewood et al. 1986; Ricci Lucchi, 1986; DeCelles \& Giles, 1996; Lacombe et al. 2007). Similarly, the distinction between toe-troughs (or foredeeps sensu stricto, where a basin accumulates sediments ahead of an active thrust system) and thrust-sheet-top basins (or piggyback basins, resting on top of moving thrust sheets), dates back to the same period (Ori \& Friend, 1984). However, the simple notion of forelandward depocentre migration and of foredeep vs piggyback sedimentation is challenged in situations of changing thrusting style, from detachment- to crustal ramp-dominated (Giamboni et al. 2004; Butler \& Mazzoli, 2006; Von Hagke et al. 2012), as well as in multi-stage thrust belts such as the Zagros (e.g. Alavi, 1994), the Pyrenees (e.g. Muñoz, 1992), the Alps (e.g. Mosar, 1999; Handy et al. 2010) or the Oman Mountains (Boote et al. 1990; Tarapoanca et al. 2010). In these latter cases, shortening renewal causes uplift of a partly eroded thrust belt and further forelandward migration of flexural subsidence. Neither the shortening direction nor thrust location and propagation sequence for the two stages necessarily overlap. As a consequence, the evolution of the two foreland basins can evolve significantly differently in terms of both style and position, as observed for example in the Zagros (e.g. Saura et al. 2015). Understanding the evolution of a multi-stage thrust belt thus requires evaluating the tectonostratigraphic evolution of the different tectonic pulses that controlled its development. In turn, this requires detailed structural studies to be carried out on the different portions of the syn-orogenic sedimentary pile. 

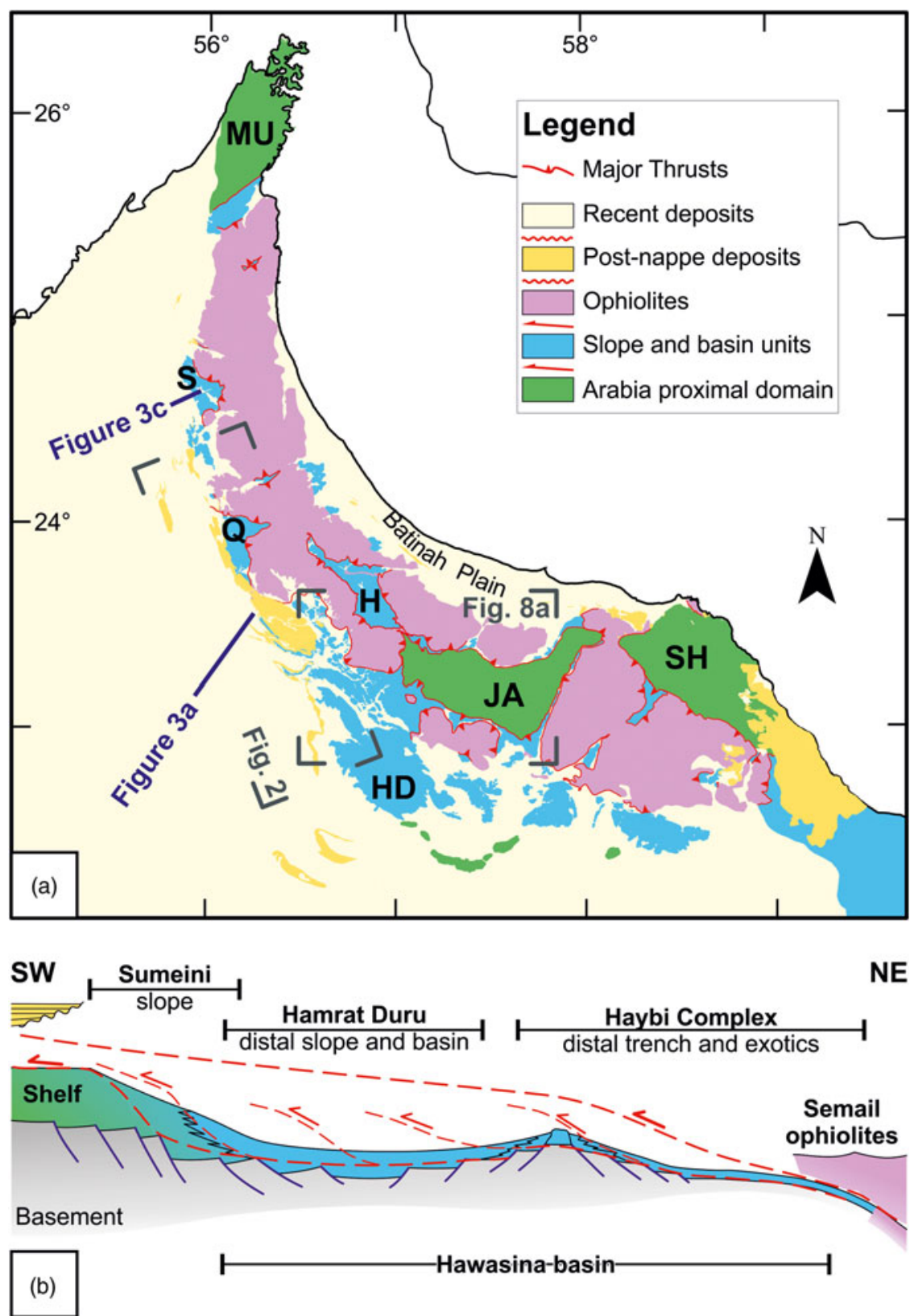

Fig. 1. (Colour online) (a) Simplified geological map of the Al-Hajar Oman Mountain Belt. Locations of Figures 2, 3 and $8 \mathrm{a}$ are indicated. (b) Diagram showing the early-orogenic framework of the different Mesozoic domains. MU (Musandam), JA (Jabal Akhdar) and SH (Saih Hatat) are the three main tectonic windows exposing the Arabian Platform domain. S (Sumeini) and $\mathrm{Q}$ (Qumayrah) are half-windows, and $\mathrm{H}$ (Hawasina) is a tectonic window (slope and basin units are exposed). HD is the Hamrat Duru range.

The Al-Hajar mountain belt (Fig. 1a) is an outstanding example of polyphase mountain building, recording two main shortening stages. The first is very well constrained by the remarkable obduction of one of the most studied ophiolite complexes in the world, the Semail ophiolite (Searle, 2014 and references therein). This ophiolite complex overthrusted southwestward the deformed Arabian passive margin during the Late Cretaceous, including the imbricated pelagic sediments of the Hawasina Basin (Fig. 1b; Glennie et al. 1973; Béchennec et al. 1988). This shortening event was associated with uplift and erosion of the forebulge and deposition of syn-tectonic sediments of the Aruma Group (Nolan et al. 1990; Béchennec et al. 1992) ahead of the advancing wedge. In the foredeep, these syn-tectonic sediments are overlain by postkinematic latest Cretaceous to Eocene carbonates, commonly referred to as the post-nappe package. This package thins toward the interior of the belt, where it unconformably overlies the different Cretaceous nappes. The second shortening event led to the re-deformation of the Cretaceous tectonic pile, along with the post-nappe package. This event is definitely more intricate and less constrained. Its stratigraphic record is scarce and consists of late Eocene-Miocene syn-kinematic layers, whose youngest groups are only locally outcropping and mostly observed in seismic sections.

In this work we couple structural investigations at the mountain front with a thermochronological study in the interior of the belt, in order to obtain a comprehensive picture integrating timing of exhumation of the substratum and post-nappe stratigraphy. Defining of long-term evolution of fold-and-thrust belts and associated foreland basins is in fact fundamental for the correct assessment of their potential for hydrocarbon exploration (e.g. Roure et al. 2010). The very low closure temperature $\left(55^{\circ} \mathrm{C}<T_{\mathrm{c}}<80^{\circ} \mathrm{C}\right.$; Farley, 2000) of the apatite $(\mathrm{U}-\mathrm{Th}) / \mathrm{He}(\mathrm{AHe})$ system makes this thermochronological method the most appropriate to unravel exhumation events throughout the upper $1-2 \mathrm{~km}$ of the crust, and therefore to correlate 
thermochronology with topography erosion and unroofing of the mountain belt and sedimentation in the foreland basin. Additionally, the interpretation of seismic reflection profiles at the belt-foredeep transition allows constraining style and timing of the major mountain-building stages during the second shortening pulse. These data are integrated with the outcomes of a fieldbased structural study and remote sensing analysis carried out on the post-nappe package exposed at the mountain front. This multidisciplinary approach is expected to reveal two sub-processes connected to mountain building. Thermochronology is in fact deciphering the uplift in the culmination areas, while structural data and seismic sections show what was occurring, coevally with uplift, in the frontal areas. Our results indicate a coherent late Eocene Miocene stage of mountain building, whose understanding provides additional constraints on the structural evolution of the Oman Mountains and also has implications for the petroleum system.

\section{Geological setting of the Al-Hajar Mountains}

The Al-Hajar Mountains are a mountain range located along the eastern edge of the Arabian Platform, in NE Oman (Fig. 1a). This dominantly NW-SE-striking mountain range extends for more than $400 \mathrm{~km}$, with an arched shape and a SW-oriented convexity. Two main shortening periods are generally considered to account for its uplift and present-day geometry. A first and bestconstrained shortening event started during the Late Cretaceous, when the opening of the South Atlantic Ocean induced rotation of the Arabian-African plate and the onset of convergence in the South Tethyan Ocean. This convergence was probably initiated by an intra-oceanic NE-directed subduction (Robertson \& Searle, 1990; Searle et al. 2014; van Hinsbergen et al. 2015; Jolivet et al. 2016), followed by continental subduction of the thinned leading edge of the Arabian continental margin, as documented by intense deformation and blueschist to eclogite facies metamorphism in the Saih Hatat tectonic window (Goffé et al. 1988; Chemenda et al. 1996; Warren et al. 2003; Breton et al. 2004; Guilmette et al. 2018). These subduction processes led to the progressive SWdirected emplacement of allochthonous units (Sumeini slope deposits, Hawasina basin deposits and Haybi sedimentary and tectonic mélange complexes; Fig. 1) and of the Semail Ophiolite onto the Permo-Mesozoic continental passive margin of the Arabian Platform (Fig. 1b) (Glennie et al. 1973; Béchennec et al. 1988; Cooper, 1988; Breton et al. 2004; Searle \& Ali, 2009).

During obduction of the Semail Ophiolite and advance of the allochthonous wedge, the foreland underwent SW-migrating flexural bending with uplift and erosion of the passive-margin megasequence, creating a forebulge unconformity (Boote et al. 1990; Robertson et al. 1990; Cooper et al. 2014). Subsequently, syn-orogenic sedimentation began in the areas of peripheral bulge and backbulge (Glennie et al. 1973; Robertson, 1987), followed by shallow-water sedimentation passing northeastward to a foredeep environment where deep-water clastic sediments accumulated (Robertson, 1988; Cooper et al. 2014).

This first shortening episode and the related obduction were almost completed by early Maastrichtian time, when stable shelf conditions developed, as testified by the deposition of the Simsima Formation on top of the Qahlah fluvial conglomerates (Noweir \& Alsharhan, 2000; Abbasi et al. 2014). These latter conditions were most likely interrupted by a global eustatic sea-level fall at the end of the Maastrichtian (Searle, 2007), as recorded by the unconformity on top of the Simsima Formation, before

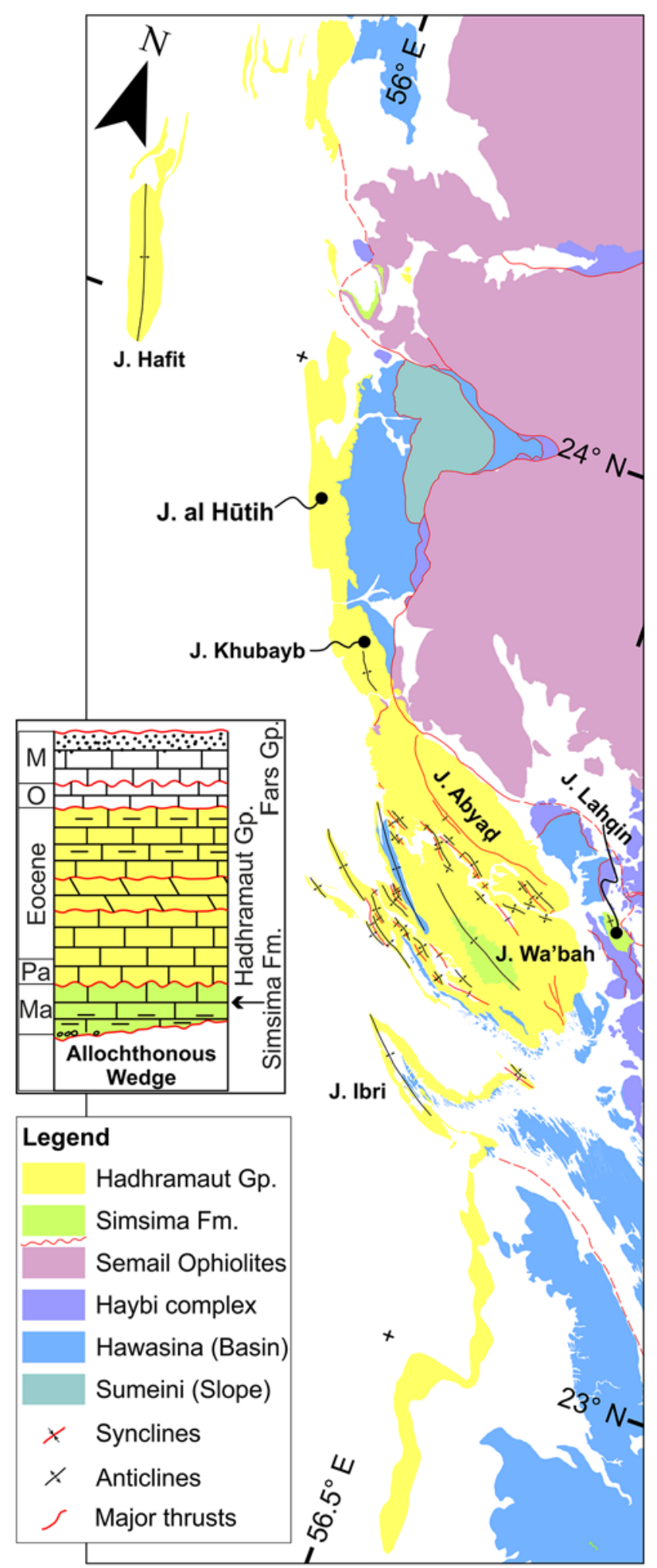

Fig. 2. (Colour online) Geological map of the frontal area of the Central Al-Hajar Oman Mountains. Due to the scale of observation, folds are only indicated in the post-nappe units (Simsima and Hadhramaut Group).

shallow-water limestone deposition was resumed during the late Palaeocene (Coleman, 1981; Nolan et al. 1990) and the Hadhramaut Group deposited throughout the Eocene (Fig. 2). After the obduction phase, a NE-SW-oriented extensional regime 
developed (Mann et al. 1990; Fournier et al. 2006; Storti et al. 2015; Grobe et al. 2018; Mattern \& Scharf, 2018) and exhumation of the high-pressure, low-temperature autochthon of Saih Hatat (Fig. 1) was achieved by a ductile extensional detachment (Goffé et al. 1988; Michard et al. 1994; Searle et al. 1994, 2004; Chemenda et al. 1996; Gregory et al. 1998; Searle \& Cox, 2002; Fournier et al. 2006). Extensional NW-SE-striking fault systems developed in central Oman (Mann et al. 1990; Fournier et al. 2006; Al-Wardi \& Butler, 2007; Holland et al. 2009; Virgo, 2015; Scharf et al. 2016; Hansman et al. 2018; Mattern \& Scharf, 2018), and along the eastern edge of the Al-Hajar Mountains (e.g. in the Batinah Coastal Plain; Mann et al. 1990). However, the frontal portion of the belt was poorly affected by this late orogenic extension event.

A second shortening phase occurred during the Cenozoic and it is responsible for the deformation of the Late Cretaceous to Cenozoic post-nappe package and for the final uplift and doming of the culmination areas of the central Al-Hajar Mountains (Mount et al. 1998; Breton et al. 2004; Csontos et al. 2010; Ali et al. 2014; Cooper et al. 2014; Hansman et al. 2017). This uplift event was constrained by several thermochronological data (Mount et al. 1998; Poupeau et al. 1998; Saddiqi et al. 2006; Wübbeler et al. 2015; Hansman et al. 2017; Grobe et al. 2019) and absolute radiometric dating of veins (Grobe et al. 2018; Hansman et al. 2018) from the Jabal Akhdar and Saih Hatat tectonic windows and surrounding areas (Fig. 1a). Moreover, extensive fluid circulation during forebulge development, thrust emplacement and tectonic loading was described in the northern sector of the belt (Breesch, 2008; Breesch et al. 2010, 2011; Callot et al. 2017). Despite this large amount of data, the timing and mode of exhumation of the main tectonic windows is still debated. Nevertheless, most recent interpretations point toward a rapid exhumation of the Jabal Akhdar Dome (Hansman et al. 2017; Grobe et al. 2019) starting from the early Eocene.

\section{Study area}

Structural investigations were carried out along the mountain front in the central portion of the belt, where the post-nappe package is exposed (Fig. 2). Termochronological analysis was instead focused on samples collected in a more internal position of the belt.

The mountain front in the study area is characterized by a nearly NNW-SSE elongated ribbon of post-nappe sediments interposed between the foreland area (covered by Quaternary alluvial, slope and aeolian deposits) and the frontal portion of belt. The latter is characterized by an uppermost nappe, composed of the Semail Ophiolites, placed on top of a SW-verging thrust system deforming the Mesozoic sedimentary cover of the Arabian margin (including the Haybi Complex, the Hawasina Basin and the Sumeini Slope; Fig. 1b). The post-nappe layers unconformably cover these Mesozoic strata and, at a few places, the ophiolites. In detail, the older terms of the post-nappe succession belong to the Maastrichtian Qahlah and Simsima formations. However, though widely described along the frontal part of the belt to the north (e.g. Noweir \& Alsharhan, 2000; Searle \& Ali, 2009), in the study area the fluviatile to shallow-marine clastic sediments of the Qahlah Formation are missing (Rabu et al. 1993) and the shallow-marine limestones of the Simsima Formation, which are widely exposed at the Jabal Wa'bah area and at Jabal Lahqin (Fig. 2), lie directly on top of the nappes. The thickness of the Simsima Formation is also very variable, passing from the thickest section at Jabal Lahqin (with more than $250 \mathrm{~m}$ ) to absent at Jabal
Ibri (Rabu et al. 1993 and references therein). Above a regional unconformity, the overlying strata of the Palaeocene-Eocene Hadhramaut Group are widely exposed and mostly rest on top of the Mesozoic Hawasina Basin, where the Simsima Formation is either not preserved or not deposited. The overlying OligoMiocene strata are instead poorly outcropping in the area. These are only exposed in the northern sector of the belt, as it occurs on the flanks of the Jabal Hafit anticline (Hansman \& Ring, 2018 and references therein), and are mostly found in exploration wells.

\section{3.a. Seismic sections}

Seismic sections crossing the mountain front allow constraints to be set on the timing of deformation (Fig. 3). In the southern section (Fig. 3a), the Pre-Cambrian to Cretaceous layers of the autochthonous domain are gently NE-dipping. They are well imaged in the SW portion of the section, where they are overlain by the postnappe succession, whereas to the NE they are in the footwall of the allochthonous wedge. This wedge forms a triangularly shaped area (Aldega et al. 2017) delimited upward by an erosional unconformity. The Aruma Group seals both the allochthonous wedge and the autochthonous sedimentary sequence, and the entire post-nappe is coherently folded to form a $50 \mathrm{~km}$ wide gentle syncline, with $2-5 \mathrm{~km}$ wavelength folds affecting the Hadhramaut Group in the NE portion of the section. Flattening of the seismic line at the top of the Hadhramaut Group (Fig. 3b) shows how the first foredeep was almost completely sealed by the Aruma Group. The top of the Aruma Group and the top of the Hadhramaut Group are only very slightly $\left(<2^{\circ}\right.$ in our vertically exaggerated representation) oblique to each other. The Oligo-Miocene sequence is instead characterized by a marked southwestward thinning, revealing that flexural subsidence during the OligoMiocene interval was already going on. Such a two-stage flexuring of the foredeep is illustrated in the inset of Figure $3 \mathrm{~b}$, where the approximate age of reflectors is plotted vs the angle that each reflector forms with the top Miocene layer (computed on the vertically exaggerated flattened seismic line in Fig. $3 \mathrm{~b}$ ). The graph shows the occurrence of a progressive decrease of the angle between 100 and $65 \mathrm{Ma}$, followed by a period during which the angle was constant, between 65 and $45 \mathrm{Ma}$, and a second decreasing period between 45 and $10 \mathrm{Ma}$. These three stages correspond to: (i) a first period of flexural subsidence and foredeep infill; (ii) a tectonically quiescent period during which no differential subsidence occurred; (iii) a renewed flexural subsidence, corresponding to a second foredeep stage, which started at c. $45 \mathrm{Ma}$, i.e. during the late Eocene.

The seismic section to the north (Fig. 3c) displays a slightly more internal (and deformed) portion of the foreland. In the western portion of the line, layers of the Autochthonous units, Aruma Group, Hadhramaut Group and Oligocene units are nearly parallel and NE-dipping. In the central and NE portion of the line, by contrast, the Aruma and Hadhramaut groups unconformably overlie the allochthonous nappes, and are folded and uplifted. The lower portion of the Fars Group is coherently folded with the underlying Hadhramaut Group, and is unconformably overlain by Miocene strata. The unconformity dates the onset of folding at the Miocene. However, reactivation of the allochthonous wedge is older, as shown in the flattened seismic line-drawing (Fig. 3d). Flattening at the top of the Hadhramaut shows a geometry similar to that observed to the south, with the top and the base of the Hadhramaut Group being only slightly oblique to each other, 

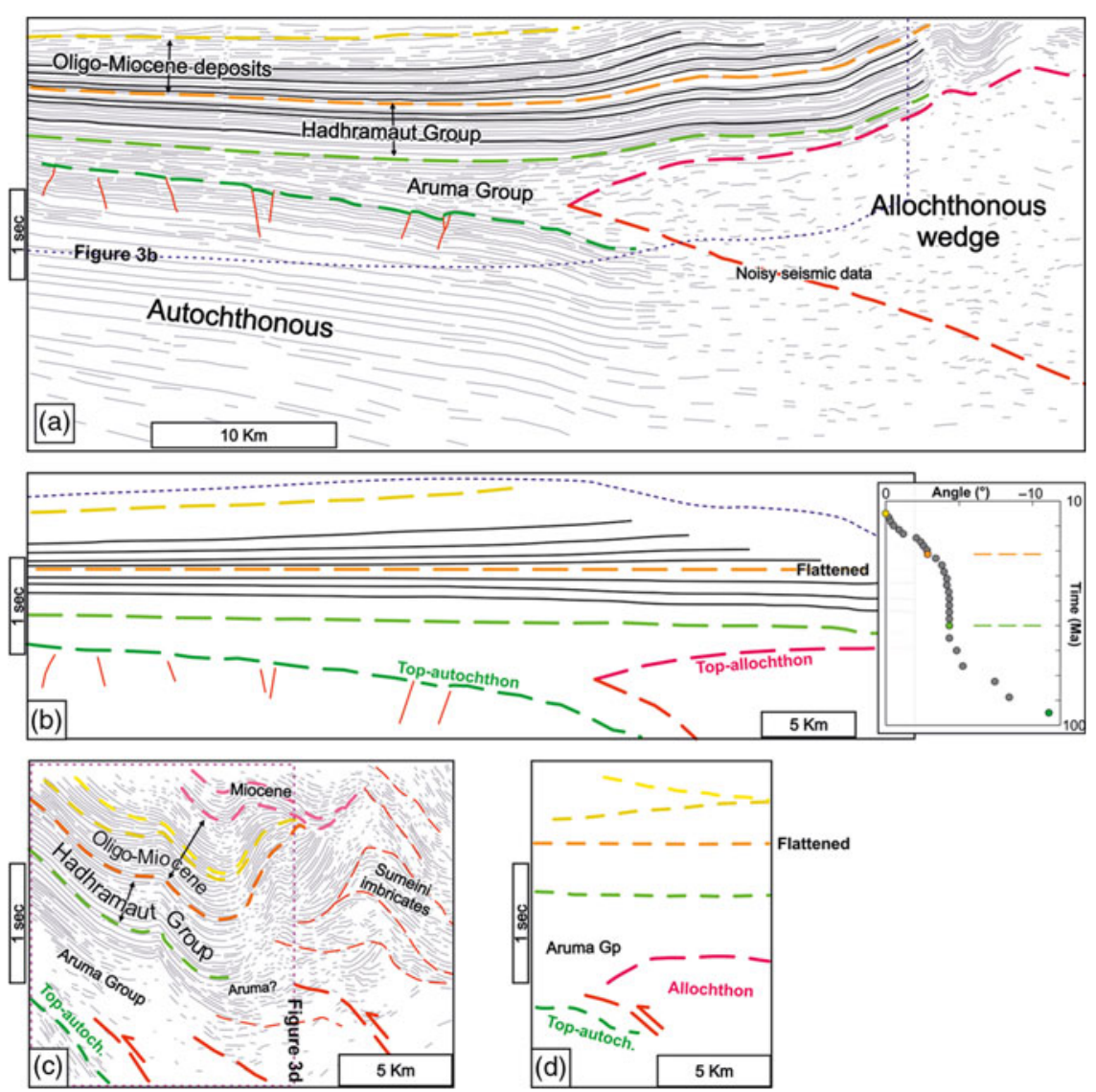

and the Oligocene package thickening toward the NE. This indicates again that renewal of flexural subsidence started before the Oligocene. The flattened seismic line-drawing also shows that the uppermost portion of the Oligo-Miocene package is NE-thinning. Although this portion of the multilayer rests below the major Miocene unconformity seen in this section, the northeastward thinning points to a generalized Oligo-Miocene uplift of the allochthonous wedge, followed by Miocene folding and thrusting.

\section{3.b. Structural data}

Attitudes of bedding surfaces were acquired by two different methods. A preliminary remote sensing approach (Fig. 4) was employed using the software Openplot (Tavani et al. 2011). Data extraction was obtained by the best fit of polylines drawn over three-dimensional objects (e.g. Fernández et al. 2009). Threedimensional objects for data extraction were derived draping $2 \mathrm{D}$ images (i.e. aerial imageries and geological maps) over the ASTER Global DEM v2 (30 m x-y resolution, provided by the US Geological Survey at https://gdex.cr.usgs.gov/gdex/). A selection of the resultant best-fit planes was made in real time (e.g. Corradetti et al. 2017, 2018) to discard those planes affected by rough error. For instance, typical sources of error were the low resolution of the model or the colinearity of the digitized polylines (e.g. Fernández et al. 2009; Jones et al. 2016; Seers \& Hodgetts, 2016). More than 700 bedding attitudes were extracted in this way. Approximately 300 further bedding attitude data were collected in the field, together with mesoscale fault and fold data.
Fig. 3. (Colour online) (a) Line drawing of a seismic image in time domain (see Fig. 1 for location) showing the allochthonous wedge (made by slope to Hawasina's basin deposits and ophiolites) thrusted onto the autochthonous Arabian platform. The post-nappe Palaeocene Eocene Hadhramaut Group succession blanketed the wedge and the Autochthonous prior to further uplift that resulted in the folding of the post-nappe units. (b) Line-drawing interpretation flattened at the level of around-top Hadhramaut Group, and inset showing inclination variation through time of several reflectors as resulting at the scale of Figure Fig. $3 \mathrm{~b}$. (c) Line drawing of a seismic image located in front of Jabal Sumeini half-window (see Fig. Fig. 1 for location) showing an imbricated stack wedge reactivated during Oligo-Miocene time, and (d) line-drawing interpretation of the southwestern part flattened at the level of around-top Hadhramaut Group.
Faults, small-scale folds and bedding data from the post-nappe sedimentary succession were acquired in the frontal portion of the belt, in the area of Figure 2. The regional trend of map-scale folds involving the Hadhramaut Group in this area slightly changes from north to south, being $c .155^{\circ}$ in the Jabal Hafit structure to the north, and $c .130^{\circ}$ toward the south (Fig. 2). This gentle change mimics the arcuate shape of the Al-Hajar Mountains. Both the remotely sensed bedding attitude and the bedding collected in the field from the post-nappe show a positive overlap and display a poles distribution along a $\mathrm{N}^{\circ} 9^{\circ}$-striking plane (Fig. 5a, b). Bedding attitude and fold data were also collected from the three main tectonic windows into the slope and basin deposits $(\mathrm{H}, \mathrm{S}$ and Q in Fig. 1) and in the Hamrat Duru range (HD in Fig. 1) for direct comparison with Cenozoic deformation affecting the post-nappe sedimentary units. The cumulative contour plot of fold hinges collected from these structural domains shows a maximum corresponding to folds having sub-horizontal axes trending $\mathrm{N} 125^{\circ}$ (Fig. 5c). In detail, the contour plot of poles to bedding from the Hamrat Duru range to the south (Fig. 2) shows a well-clustered distribution of poles, which are aligned along a N41 ${ }^{\circ}$-striking vertical plane (Fig. $5 \mathrm{~d}$ ). In the Hawasina window, poles to beddings are still well distributed along a NE-SW direction (Fig. 5e). To the north, in the Sumeini and Qumayrah windows, the distribution of poles to bedding is slightly rotated and distributed along an ENE-WSW direction. The spread of structural data in these latter two windows (Fig. 5f, g) is likely due to limited fold cylindricity and related sampling bias - associated with the abundance of periclinal closures at measurement sites located along main road cuts. Overall, poles to bedding in the Cretaceous nappes follow the 
Fig. 4. (Colour online) Workflow followed for the data extraction from 3D models. The model is created draping an orthophoto (1) over a DEM (2). From the resulting 3D model (3) a polyline is digitized in OpenPlot software and a best-fit plane corresponding to the attitude of the bedding automatically calculated and eventually accepted (4) by the user.

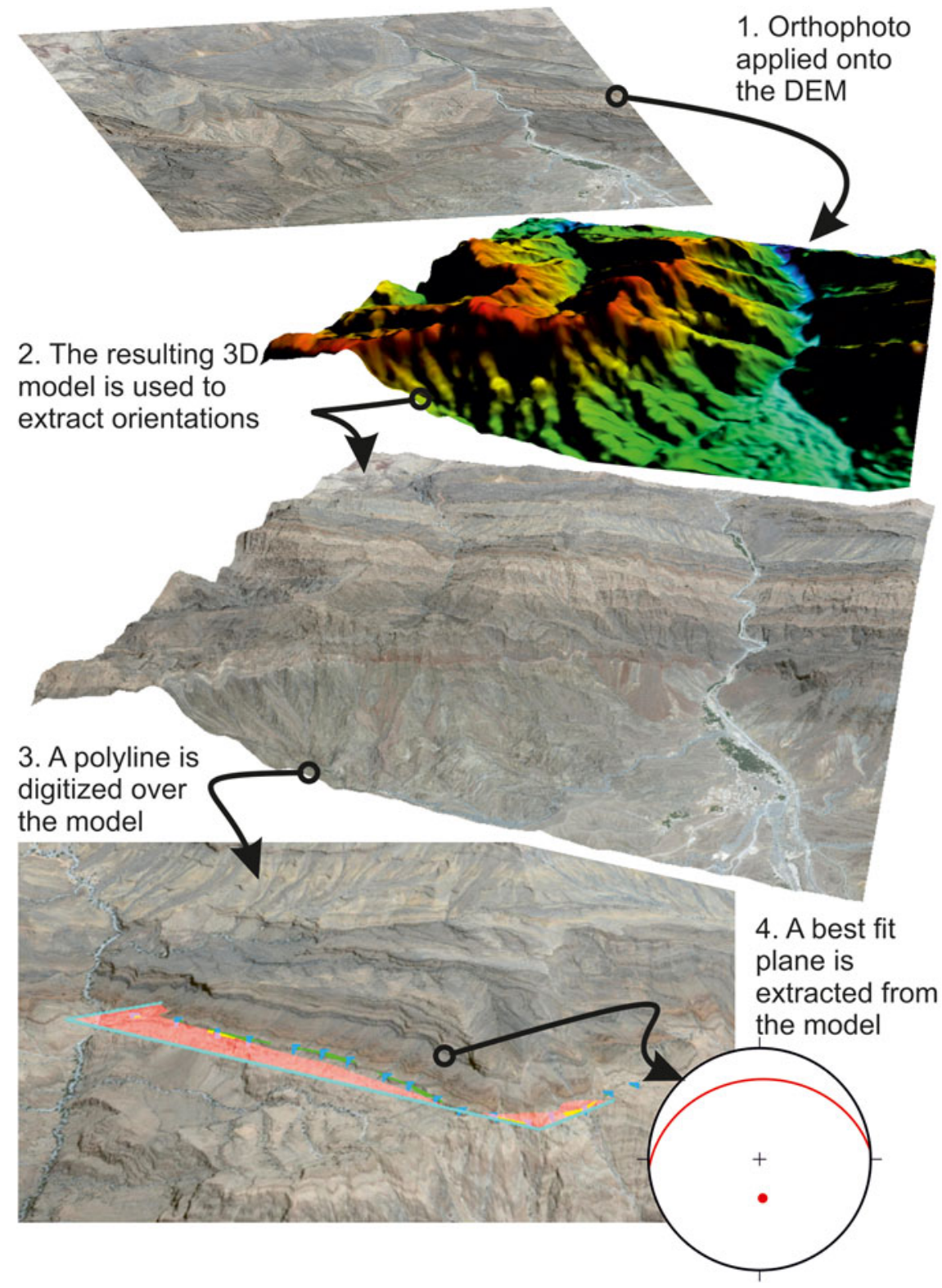

regional trend of the post-nappe succession, which in turn follows the arcuate shape of the belt.

Unlike the Cretaceous nappes, the post-nappe package is characterized by the remarkable absence of far-travelled thrust sheets. The most important deformation structures, both at the seismic and outcrop scales, are folds. Reverse faults occur mostly as accommodation structures associated with folds, being thus a hierarchically lower-order structure. In the post-nappe succession, folds occur at various scales and show wavelengths ranging from a few kilometres down to centimetres. The outcrop-scale folds (i.e. $10 \mathrm{~cm}<$ wavelength $<100 \mathrm{~m}$ ) have NW-SE-trending axes and span from open to almost isoclinal (Fig. 6). Many folds have near-vertical axial surfaces (Fig. 6a), while others display hinterlandward dipping axial surfaces (Fig. 6b, c) consistent with the vergence of the fold-and-thrust belt. The well-bedded nature of the post-nappe carbonates promoted flexural-slip folding, sometimes of disharmonic type (Fig. 6a, b). The intersection of conjugate reverse fault sets is generally parallel to the fold axes (Fig. 6a-e), thus suggesting a coeval development during the same shortening event, although superposed $\mathrm{N}-\mathrm{S}$-oriented striae and shear fibres were locally observed postdating the SW-NE-oriented ones. Post-nappe layers also hold a set of conjugate strike-slip faults (Fig. 7). Their dihedral angle is nearly $60^{\circ}$ and they are found both in sub-horizontal strata (Fig. 7a) and in near-vertical strata (Fig. 7b), where they are tilted together with the beds. In both cases, the acute bisector of the conjugate system strikes nearly NE-SW, in agreement with the shortening direction provided by folds and thrusts.

\section{3.c. Low-temperature thermochronometry}

New AHe data were obtained in this study. Helium is produced by the decay of $U$ in a time-dependent function (Hourigan et al. 2005). The closure temperature for $\mathrm{He}$ in apatite is between $80^{\circ} \mathrm{C}$ and $55^{\circ} \mathrm{C}$ (Farley, 2000). Considering a standard geothermal gradient of $25-30{ }^{\circ} \mathrm{C} \mathrm{km}^{-1}$, and an average surface temperature of $c .30^{\circ} \mathrm{C}$ (at present-day latitude), AHe cooling ages record the time when a rock sample passed through the depth between $c .1$ and $2 \mathrm{~km}$. 

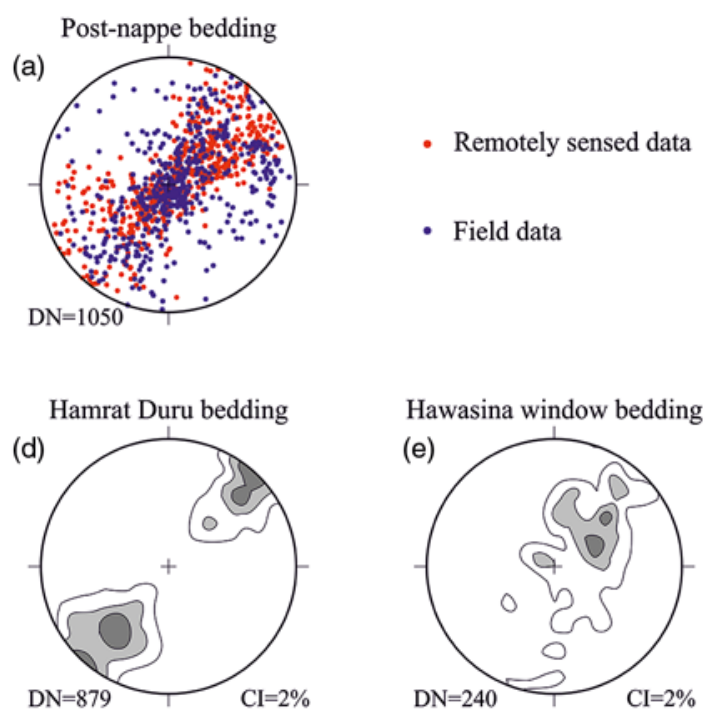

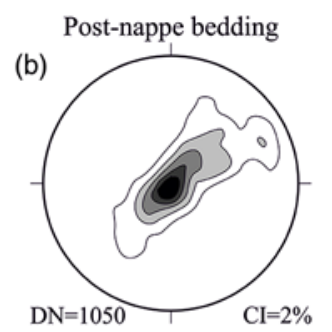

Fold axes in basin\&slope

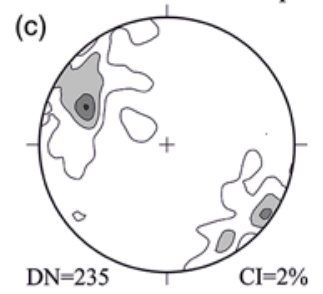

Qumayrah window bedding
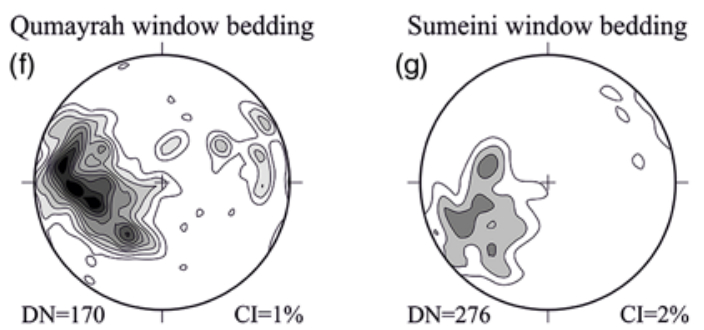

Fig. 5. (Colour online) (a) Poles to bedding collected in the post-nappe Upper Campanian - Maastrichtian Simsima Formation (Aruma Group) and Palaeocene-Eocene Hadhramaut Group from remote sensing in Openplot (red dots) and from direct field acquisition (blue dots). (b) Cumulative density contour of poles to bedding in the post-nappe succession. (c) Cumulative density contour of fold hinges collected from Sumeini (slope) and Hawasina (basin) units from the different windows. $(\mathrm{d}-\mathrm{g})$ Cumulative density contour of poles to bedding in the Hamrat Duru, Hawasina, Qumayrah and Sumeini windows. Here and in the following, plots are in lower hemisphere, equal-area projection. $\mathrm{DN}$ is the number of observations and $\mathrm{Cl}$ is the contour interval.

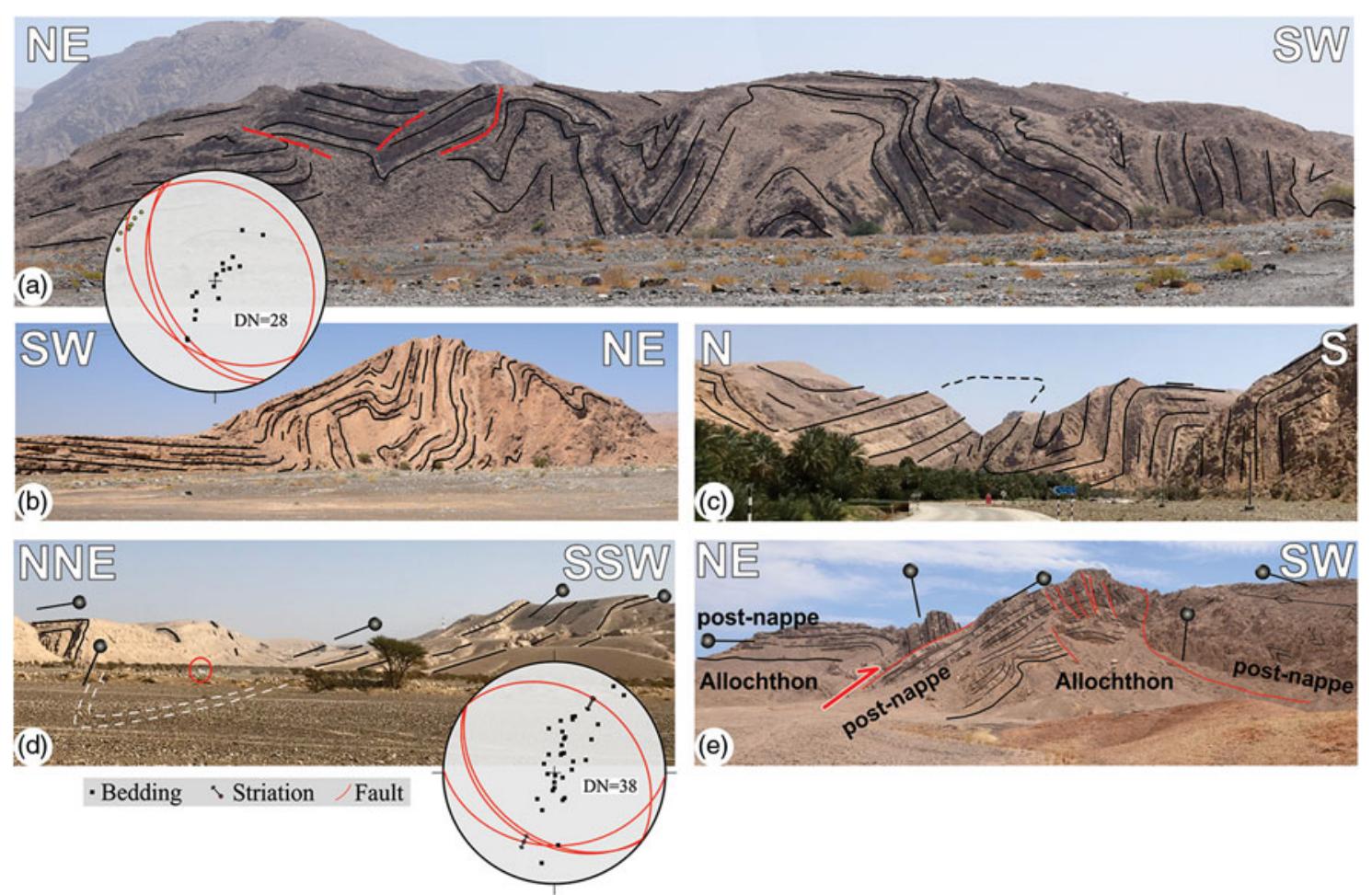

Fig. 6. (Colour online) Examples of disharmonic detachment folding. (a) Folded strata in the Hadhramaut Group in Jabal Wa'bah showing only minor faulting ( $23^{\circ} 30^{\prime} 21.1^{\prime \prime} \mathrm{N}, 56^{\circ}$ $26^{\prime} 43.0^{\prime \prime} \mathrm{E}$ ). (b) Box fold along the same axial direction of the previous fold ( $\left.23^{\circ} 30^{\prime} 39.8^{\prime \prime} \mathrm{N}, 56^{\circ} 25^{\prime} 59.5^{\prime \prime} \mathrm{E}\right)$; stereoplot shows cumulative data for (a) and (b). (c) Larger-scale box folds within the post-nappe succession ( $\left.23^{\circ} 30^{\prime} 13.9^{\prime \prime} \mathrm{N} 56^{\circ} 28^{\prime} 52.0^{\prime \prime} \mathrm{E}\right)$. (d) Large-scale SW vergent folds at Jabal Ibri ( $\left.23^{\circ} 19^{\prime} 33.4^{\prime \prime} \mathrm{N} 56^{\circ} 31^{\prime} 27.0^{\prime \prime} \mathrm{E}\right)$. (e) Reverse faults within the Hadhramaut Group involving the allochthonous wedge ( $\left.23^{\circ} 22^{\prime} 30.47^{\prime \prime} \mathrm{N}, 56^{\circ} 24^{\prime} 50.48^{\prime \prime} \mathrm{E}\right)$.

Eleven rock samples were collected (Fig. 8a) in siliciclastic rocks from different structural domains of the mountain belt for $\mathrm{AHe}$ analysis. In detail, seven samples were collected from the upper Matbat Formation (Jurassic) of the Hamrat Duru Group of the Hawasina Basin, two from the syn-tectonic Muti Formation of the Aruma Group, one from the quartzitic member of the autochthonous Jurassic Sahtan Group and one from a quartzitic level in Precambrian autochthonous. Samples were prepared at Géosciences Environnement Toulouse (GET), and He was analysed at Géosciences Montpellier. Extracted apatite grains presented mostly rounded shapes related to abrasion (Fig. 8b). Several samples did not furnish apatite crystals, or have 
Fig. 7. (Colour online) Examples of pre-folding layer-parallel shortening. (a) Beddingperpendicular, soft-sediment, strike-slip deformation bands at Jabal Ibri $\left(23^{\circ} 15^{\prime} 37.02^{\prime \prime} \mathrm{N}\right.$, $\left.56^{\circ} 25^{\prime} 12.40^{\prime \prime} \mathrm{E}\right)$. (b) Bedding-perpendicular strike-slip faults (normal faults in present-day attitude) at about $60^{\circ}$ to each other in subvertical Eocene strata at Jabal al Hūtih $\left(23^{\circ} 54^{\prime} 11.27^{\prime \prime}\right.$ $\left.\mathrm{N}, 56^{\circ} 3^{\prime} 23.55^{\prime \prime} \mathrm{E}\right)$.
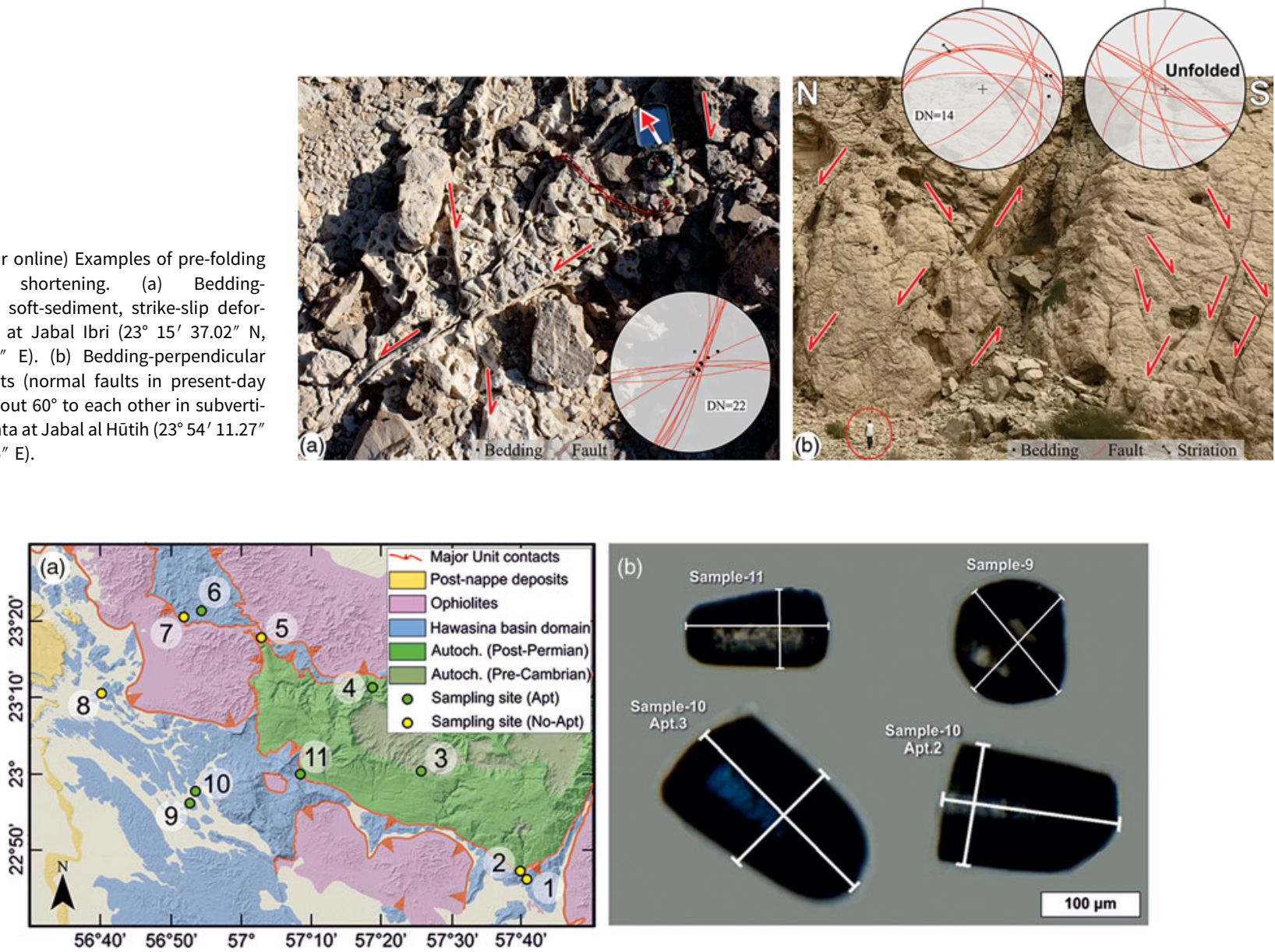

Fig. 8. (Colour online) (a) Locality sampled for (U-Th)/He dating of apatite crystals. Samples that yielded apatite crystals are marked in green, those that did not furnish any are shown in yellow. Sample numbers are circled (see Table 1 for cooling ages). (b) Examples of apatite crystals extracted from the collected samples. Crystals present rounded shapes due to transport and abrasion.

crystals of quality (due to inclusions) suitable for AHe analysis (Table 1). These samples were anyway included in Table 1 , in order to provide information on the likelihood of finding well-preserved apatites from different lithostratigraphic units.

AHe ages were obtained on carefully selected apatite grains with a minimum width of $60 \mu \mathrm{m}$, which have been measured along the two axes on two faces (each sample aliquot for $\mathrm{He}, \mathrm{U}$ and Th determinations typically comprises apatite grains $\sim 80-310 \mu \mathrm{m}$ long and $\sim 60-130 \mu \mathrm{m}$ wide). The grains were placed on a platinum tube and heat at $1050{ }^{\circ} \mathrm{C}$ for $5 \mathrm{~min}$ with a diode laser. Evolved helium was spiked with ${ }^{3} \mathrm{He}$ and purified, and the ${ }^{4} \mathrm{He} /{ }^{3} \mathrm{He}$ ratio determined by quadrupole mass spectrometry after quantitative He degassing of apatite. Grains were retrieved from the vacuum system, dissolved in $\mathrm{HNO}_{3}$ for apatite, spiked with ${ }^{230} \mathrm{Th},{ }^{235} \mathrm{U}$, and analysed for $\mathrm{U}$ and $\mathrm{Th}$ by inductively coupled plasma mass spectrometry. Helium ages were corrected for alpha ejection effects $\mathrm{F}_{\mathrm{T}}$ (Farley et al. 1996) based on grain dimensions determined using the Monte Carlo simulation technique of Ketcham et al. (2011) and equivalent-sphere radius with the procedure of Gautheron \& Tassan-Got (2010). Each age typically comprises one to four replicates, and many have only one grain. The estimated analytical uncertainty for $\mathrm{He}$ ages based on age standards is c. $7 \%$ for Durango apatite $(2 \sigma)$.

The Matbat Formation was the most sampled lithology (samples 1, 6-11 in Fig. 8a and Table 1). Four out of seven samples yielded at least one apatite crystal of adequate quality for the analysis. One of these samples (sample no. 10 in the Hamrat Duru range) was particularly suitable for the analysis, with four apatite crystals providing a mean radiometric age of $20.1 \pm 2.5 \mathrm{Ma}$. Sample no. 6 (in the Hawasina window) yielded two crystals with a mean cooling age of $15.3 \pm 1.4 \mathrm{Ma}$. Two samples (nos. 9 and 11 ) yielded one crystal each, with ages of $42 \pm 3$ and $38.2 \pm 2.7$ Ma respectively.

Two crystals were found from sample no. 3 , collected from sandstone strata within the Pre-Permian stratigraphic sequence (Fig. 8a). According to the BRGM (Bureau de recherches geologiques et minières, France) geological maps (Béchennec et al. 1992), this locality is mapped as Mu'aydin Formation, where sandstones are expected at the contact with the underlying Hajir Formation. These crystals gave dissimilar radiometric ages of $42.3 \pm 3.0 \mathrm{Ma}$ and $17.3 \pm 1.2 \mathrm{Ma}$ that could be explained by a partial reset of the system or by issues related to: (i) undetected inclusions, (ii) specific composition of apatite such as $\mathrm{Cl}$ content of high eU concentration (Gautheron et al. 2013; Murray et al. 2014; Recanati et al. 2017) and/or (iii) broken grains (difficult to notice since grains are rounded; Brown et al. 2013). Both ages are anyway in the range of previous observations made in other localities for the Jabal Akhdar culmination, where single-grain ages have shown values ranging between $39 \pm 2 \mathrm{Ma}$ and $10 \pm 1 \mathrm{Ma}$ (e.g. Hansman et al. 2017; Grobe et al. 2019). 
Only one crystal, with a cooling age of $24.3 \pm 1.7 \mathrm{Ma}$, was found in sandstones of the Sahtan Group, of Jurassic age in Wadi Sahtan. No apatite crystals were found within the syn-tectonic Muti Formation in the two sampled localities (Fig. 8a).

\section{Discussion}

The internal geometry of the allochthonous wedge is mainly characterized by the contraposition of highly deformed thrust-bounded units of the Haybi complex units and the regularly spaced thrust imbricates and short-wavelength thrust-related folds of the Hamrat Duru range (Searle \& Cooper, 1986; Cooper, 1989; Robertson \& Searle, 1990). In contrast, the post-nappe succession is mainly affected by long-wavelength folds, and short-wavelength folds occur only locally. Small-displacement (i.e. $<10 \mathrm{~m}$ ) thrusts occur predominantly as accommodation structures related to folding (e.g. in fold cores), or as pre-buckle thrusts (Ramsay \& Huber, 1987). Major-displacement (i.e. $>100 \mathrm{~m}$ ) thrusts can instead be observed in areas near the frontal region of Jabal Wa'bah, where the underlying units of the wedge are also involved in late-stage deformation and are locally thrusted on top of the post-nappe sedimentary succession (Fig. 6e). The unconformity between the postnappe succession and the underlying allochthonous wedge is mainly exposed along the frontal area of Jabal Wa'bah, at the northeastern edge of Jabal Abyad, along the axial zone of the Jabal Ibri anticline, at the edges of the Jabal Lahgin syncline, and in the northeastern edges of Habal al Hūtih and Jabal Khubayb (Fig. 2). The strata below the unconformity are always altered and eroded (Searle \& Ali, 2009). In most places, strata below the unconformity are steeply dipping or/and intensely folded, whereas the overlying strata are parallel to the unconformity. No evidence of relevant shear was recorded within the unconformity in any of the localities investigated. The unconformity thus appears as a mostly welded contact. The short-wavelength folds observed in the post-nappe sequence (Fig. 6) are mainly detached within the well-layered levels of the post-nappe package, as shown by the box fold of Figure $6 \mathrm{~b}$. The long-wavelength folds which affect the post-nappe sequence and its basal unconformity, instead, require the involvement of the allochthonous units.

Seismic sections illustrated in Figure 3 indicate the occurrence of two overlapping foredeeps in the area: a Late Cretaceous one and an Eocene-Miocene one. The first foredeep developed ahead of the Upper Cretaceous belt, and its syn-orogenic infill is the lower portion of the Aruma Group (Fig. 9a), i.e. the late ConiacianSantonian Muti Formation and the Campanian Fiqa Formation (Robertson, 1988; Boote et al. 1990; Warburton et al. 1990). Starting from the Maastrichtian, a period of tectonic quiescence was established. The belt was progressively eroded and the foredeep was contextually filled by the upper portion of the Aruma Group and subsequently by the upper-Palaeocene Eocene Hadhramaut Group, these groups being separated by a regional unconformity. In more detail, the foredeep was almost completely filled at the end of the Maastrichtian, and the overlying Hadhramaut Group deposited in a basin where no differential subsidence was occurring (Fig. 9b). Renewal of differential subsidence started during the late Eocene, with the deposition of the upper portion of the Hadhramaut Group (Fig. 9c), as imaged by the flattened seismic section interpretations and inset shown in Figure 3.
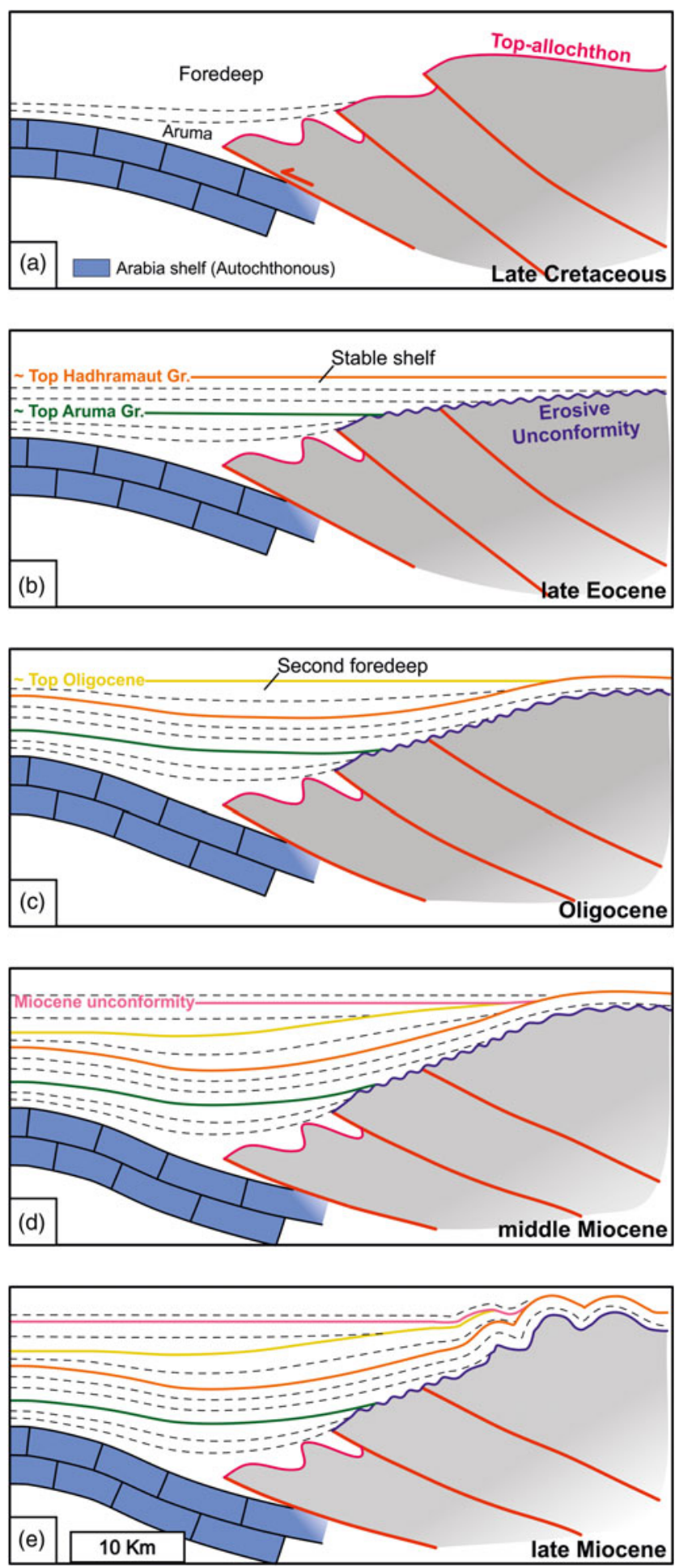

Fig. 9. (Colour online) Cartoon showing the two-dimensional tectonic evolution of the study area. (a) Foredeep development ahead of the advancing wedge with synorogenic latest Cretaceous infill. (b) Stable shelf conditions developed over an erosive surface on top of the wedge since the Maastrichtian and lasted through the deposition of the upper-Palaeocene - Eocene Hadhramaut Group. During the late Eocene renewal of differential subsidence signified the onset of a new foredeep (c). (d) Between Oligocene and Miocene time the direction of the pinch-out changed as a consequence of an almost rigid tilting on top of the wedge. (e) Folding of the post-nappe layers at the mountain front is late-stage and occurred during the late Miocene. 
Recent thermochronology studies using multiple thermochronometric systems (e.g. Hansman et al. 2017 and references therein) point out how central Oman orogeny developed during the late Eocene and middle Miocene. Two main exhumation stages are recognized at 45-40 Ma (Tarapoanca et al. 2010; Jacobs et al. 2015) and at 20-15 Ma (Jacobs et al. 2015). An older exhumation phase involved the Jabal Akhdar culmination at $64 \pm 4 \mathrm{Ma}$ (Grobe et al. 2018 ) and was associated with top-to-NNE, post-obduction extensional shear zones that did not affect the frontal part of the belt. AHe cooling ages obtained in this study fall into two main clusters, at c. $42 \mathrm{Ma}$ and $17 \mathrm{Ma}$. The use in this work of a single thermochronometric system, and with only one sample having more than two apatite grains, does not allow us to produce a reliable $t-T$ history for the whole belt. This is because with only one aliquot it is not possible to know whether there was any reset of the system. Nevertheless, our new data are in agreement with previous thermochronological results (Hansman et al. 2017; Grobe et al. 2018) and provide further evidence for the two-stage exhumation of the substratum of the post-nappe succession also in our study area. The $\sim 42 \mathrm{Ma}$ exhumation ages are related here to a major shortening event affecting the whole nappe edifice. Thrust-ramp-related uplift and associated enhanced erosion led to unroofing of the mountain belt, while the increased topographic load triggered flexuring of the lower plate (Homewood et al. 1986) and thus the development of a new foredeep, consistently with our observation at the mountain front. Uplift of the chain and coeval subsidence of the foredeep cannot be explained, instead, by a process of slab detachment that would rather provoke uplift of the whole system. On the other hand, there could be a contribution by lithospheric buckling. Nevertheless, this should be minimal, taking into account the abrupt structural difference at the mountain front, representing a relatively short-wavelength deformation not compatible with lithosphere buckling. After this stage, during the Miocene, the inner portion of the foredeep was uplifted. This is witnessed by the switch of the pinch-out direction between Oligocene and Miocene packages observed in the section of Figure $3 \mathrm{c}$. This stage, which is not recorded in the section to the south, corresponds to a wedge-top setting sensu DeCelles \& Giles (1996). The uplift was probably triggered by the reactivation of the toe portion of the allochthonous sole thrust, as suggested by the almost rigid tilting of a wide area on top of the wedge (Fig. 9d). Folding observed in the NE portion of the northern seismic sections of Figure $3 \mathrm{c}$ is younger than tilting of the allochthonous wedge, as indicated by the folded unconformity between Miocene and Oligocene strata observed in the northern seismic section. Accordingly, folding of the postnappe layers observed along the mountain front is to be regarded as a late-stage event (Fig. 9e). This late event also produced further unroofing of the mountain belt, which is recorded by the younger cluster of AHe ages at $\sim 17 \mathrm{Ma}$. This younger episode was previously related to the Zagros orogeny (Jacobs et al. 2015; Grobe et al. 2018, 2019) and to a velocity variation of the Makran subduction (Hansman et al. 2017, 2018). The layer-parallel shortening event documented in the post-nappe strata exposed at the mountain front occurred in the period spanning between the allochthonous wedge tilting and folding of the post-nappe. This inference is coherent with similar observations made in other fold-and-thrust belts worldwide, where the layer-parallel shortening pattern develops ahead of the advancing compressive front and in the more external portion of the belt (e.g. Engelder \& Geiser, 1980; Mitra \& Yonkee, 1985; Railsback \& Andrews, 1995; Evans \& Elmore, 2006; Weil \& Yonkee, 2012; Tavani et al. 2015, 2019; Beaudoin et al. 2016).

\section{Conclusions}

Integrated field structural analysis, remote sensing and seismic interpretation were used in this study to unravel the architecture and tectonic evolution of the foreland basin postdating the Cretaceous nappe emplacement in the Oman Mountains. Development of the late-Eocene, post-nappe foredeep occurred in relation to foreland flexuring controlled by the tectonic load that, in turn, resulted from renewed shortening within the mountain belt. Unroofing, recorded by both available thermochronological data and our new AHe cooling ages (at $\sim 42 \mathrm{Ma}$ ), furnished the detrital material filling the newly developed foredeep. The inner portion of the foredeep was then uplifted during the Miocene, leading to a change of the pinch-out direction observed in seismic sections between Oligocene and Miocene foreland basin units. The Miocene sequence, deposited in a wedge-top basin setting, experienced later layer-parallel shortening and folding. This younger shortening event is also recorded by renewed unroofing of the mountain belt. This is also supported by our new thermochronometric data that shows a cluster of AHe ages at 17 Ma.

The results of this study allowed us to correlate Tertiary shortening-exhumation events that occurred in the Oman Mountains with the development and tectonic evolution of the post-nappe foreland basin. This was here achieved integrating AHe thermochronometry, furnishing exhumation timing of the culmination areas, with seismic sections and structural data of the post-nappe to decipher the deformation of the frontal areas during the main uplift events. This may have major implications for a better understanding of this classic, extensively studied mountain belt and for further oil and gas exploration in the area.

Acknowledgements. The manuscript benefited from insightful constructive revisions by François Roure and Christoph von Hagke. The authors wish to acknowledge Matteo Basilici, Jason Williams and Charlie Kergaravat for their field assistance, Sandrine Choy for her support for sample preparation at GET and Patrick Monié and Michael Bonno for $\mathrm{He}$ analyses at Géosciences Montpellier. The Geological Research Department of the Public Authority for Mining (PAM) of the Sultanate of Oman is thanked for its cooperation with the University of Camerino. Mr. Ibrahim Al Sawafi from PAM is also warmly thanked for facilitating our work during the past two years.

This work forms part of a research project funded by Total E\&P through a contract with the University of Camerino. The publication of this article was funded by the Qatar National Library.

\section{References}

Abbasi IA, Salad Hersi O and Al-Harthy A (2014) Late Cretaceous conglomerates of the Qahlah Formation, north Oman. In Tectonic Evolution of the Oman Mountains (eds HR Rollinson, MP Searle, IA Abbasi, A Al-Lazki and $\mathrm{MH}$ Al Kindi), pp. 325-41. Geological Society of London, Special Publication no. 392.

Alavi M (1994) Tectonics of the Zagros orogenic belt of Iran: new data and interpretations. Tectonophysics 229, 211-38.

Aldega L, Carminati E, Scharf A, Mattern F and Al-Wardi M (2017) Estimating original thickness and extent of the Semail Ophiolite in the eastern Oman Mountains by paleothermal indicators. Marine and Petroleum Geology 84, 18-33.

Ali MY, Cooper DJW, Searle MP and Al-Lazki A (2014) Origin of gypsiferous intrusions in the Hawasina Window, Oman Mountains: implications from structural and gravity investigations. GeoArabia 19, 17-48.

Al-Wardi M and Butler RWH (2007) Constrictional extensional tectonics in the northern Oman mountains, its role in culmination development and the exhumation of the subducted Arabian continental margin. In Deformation of the Continental Crust: The Legacy of Mike Coward (eds AC Ries, RWH Butler and RH Graham), pp. 187-202. Geological Society of London, Special Publication no. 272. 
Beaudoin N, Koehn D, Lacombe O, Lecouty A, Billi A, Aharonov E and Parlangeau C (2016) Fingerprinting stress: stylolite and calcite twinning paleopiezometry revealing the complexity of progressive stress patterns during folding: the case of the Monte Nero anticline in the Apennines, Italy. Tectonics 35, 1687-712.

Béchennec F, Le Métour J, Rabu D, Villey M and Beurrier M (1988) The Hawasina Basin: a fragment of a starved passive continental margin, thrust over the Arabian Platform during obduction of the Sumail Nappe. Tectonophysics 151, 323-43.

Béchennec F, Roger J, Le Metour J and Wyns R (1992) Geological map of Seeb, sheet NF40-03, and explanatory notes, 1:250.000. Oman: Ministry of Petroleum and Minerals, Sultanate of Oman.

Boote DRD, Mou D and Waite RI (1990) Structural evolution of the Suneinah Foreland, Central Oman Mountains. In The Geology and Tectonics of the Oman Region (eds AHF Robertson, MP Searle and AC Ries), pp. 397-418. Geological Society of London, Special Publication no. 49.

Breesch, L (2008) Diagenesis and fluid system evolution in the Northern Oman Mountains, United Arab Emirates. PhD thesis, KU-Leuven, Belgium. Published thesis, 160 pp.

Breesch L, Swennen R, Dewever B, Roure F and Vincent B (2011) Diagenesis and fluid system evolution in the northern Oman Mountains, United Arab Emirates: implications for petroleum exploration. GeoArabia 16, 111-48.

Breesch L, Swennen R, Vincent B, Ellison R and Dewever B (2010) Dolomite cementation and recrystallisation of sedimentary breccias along the Musandam Platform margin (United Arab Emirates). Journal of Geochemical Exploration 106, 34-43.

Breton JP, Béchennec F, Le Métour J, Moen-Maurel L and Razin P (2004) Eoalpine (Cretaceous) evolution of the Oman Tethyan continental margin: insights from a structural field study in Jabal Akhdar (Oman Mountains). GeoArabia 9, 41-58.

Brown RW, Beucher R, Roper S, Persano C, Stuart F and Fitzgerald P (2013) Natural age dispersion arising from the analysis of broken crystals. Part I: theoretical basis and implications for the apatite (U-Th)/He thermochronometer. Geochimica et Cosmochimica Acta 122, 478-97.

Butler RWH and Mazzoli S (2006) Styles of continental contraction: a review and introduction. In Styles of Continental Contraction (eds S Mazzoli and RWH Butler), pp. 1-10. Boulder, Colorado: Geological Society of America, Special Paper 414.

Callot J-P, Faure J-L, Roure F and Tarapoanca M (2017) Kinematic, thermal, and petroleum modeling of the northern Emirates. In Petroleum Systems Analysis: Case Studies (eds MA AbuAli, I Moretti and HM Nordgård Bolås), pp. 135-64. Tulsa, Oklahoma: American Association of Petroleum Geologists. AAPG Memoir 114.

Chemenda AI, Mattauer M and Bokun AN (1996) Continental subduction and a mechanism for exhumation of high-pressure metamorphic rocks: new modelling and field data from Oman. Earth and Planetary Science Letters 143, 173-82.

Coleman RG (1981) Tectonic setting for ophiolite obduction in Oman. Journal of Geophysical Research: Solid Earth 86, 2497-508.

Cooper DJW (1988) Structure and sequence of thrusting in deep-water sediments during ophiolite emplacement in the south-central Oman Mountains. Journal of Structural Geology 10, 473-85.

Cooper DJW (1989) A longitudinal carbonate fan from the Jurassic of the Oman Mountains: the Guweyza limestone formation of the Hamrat ad Duru. Sedimentary Geology 61, 253-75.

Cooper DJW, Ali MY and Searle MP (2014) Structure of the northern Oman Mountains from the Semail Ophiolite to the Foreland Basin. In Tectonic Evolution of the Oman Mountains (eds HR Rollinson, MP Searle, IA Abbasi, A Al-Lazki and MH Al Kindi), pp. 129-53. Geological Society of London, Special Publication no. 392.

Corradetti A, Tavani S, Parente M, Iannace A, Vinci F, Pirmez C, Torrieri S, Giorgioni M, Pignalosa A and Mazzoli S (2018) Distribution and arrest of vertical through-going joints in a seismic-scale carbonate platform exposure (Sorrento peninsula, Italy): insights from integrating field survey and digital outcrop model. Journal of Structural Geology 108, 121-36.

Corradetti A, Tavani S, Russo M, Arbués PC and Granado P (2017) Quantitative analysis of folds by means of orthorectified photogrammetric
3D models: a case study from Mt. Catria, Northern Apennines, Italy. The Photogrammetric Record 32, 480-96.

Csontos L, Pocsai T, Sasvári Á, Palotai M, Árgyelán-Bagoly G, Fodor LI, Magyari A and Al-Wardi M (2010) Structural evolution of the Hawasina Window, Oman Mountains. GeoArabia 15, 85-124.

DeCelles PG and Giles KA (1996) Foreland basin systems. Basin Research 8, 105-23.

Engelder T and Geiser P (1980) On the use of regional joint sets as trajectories of paleostress fields during the development of the Appalachian Plateau, New York. Journal of Geophysical Research 85, 6319-41.

Evans MA and Elmore RD (2006) Fluid control of localized mineral domains in limestone pressure solution structures. Journal of Structural Geology 28, 284-301.

Farley KA (2000) Helium diffusion from apatite: general behavior as illustrated by Durango fluorapatite. Journal of Geophysical Research: Solid Earth 105, 2903-14.

Farley KA, Wolf RA and Silver LT (1996) The effects of long alpha-stopping distances on (U-Th)/He ages. Geochimica et Cosmochimica Acta 60, 4223-9.

Fernández O, Jones S, Armstrong N, Johnson G, Ravaglia A and Muñoz JA (2009) Automated tools within workflows for 3D structural construction from surface and subsurface data. GeoInformatica 13, 291-304.

Fournier M, Lepvrier C, Razin P and Jolivet L (2006) Late Cretaceous to Paleogene post-obduction extension and subsequent Neogene compression in the Oman Mountains. GeoArabia 11, 17-40.

Gautheron C, Barbarand J, Ketcham RA, Tassan-Got L, Van Der Beek P, Pagel M, Pinna-Jamme R, Couffignal F and Fialin M (2013) Chemical influence on $\alpha$-recoil damage annealing in apatite: implications for (UTh)/He dating. Chemical Geology 351, 257-67.

Gautheron C and Tassan-Got L (2010) A Monte Carlo approach to diffusion applied to noble gas/helium thermochronology. Chemical Geology 273, 212-24.

Giamboni M, Ustaszewski K, Schmid SM, Schumacher ME and Wetzel A (2004) Plio-Pleistocene transpressional reactivation of Paleozoic and Paleogene structures in the Rhine-Bresse transform zone (Northern Switzerland and Eastern France). International Journal of Earth Sciences 93, 207-23.

Glennie KW, Boeuf MGA, Clarke MWH, Moody-Stuart M, Pilaar WFH and Reinhardt BM (1973) Late Cretaceous nappes in Oman Mountains and their geologic evolution. AAPG Bulletin 57, 5-27.

Goffé B, Michard A, Kienast JR and Le Mer O (1988) A case of obductionrelated high-pressure, low-temperature metamorphism in upper crustal nappes, Arabian continental margin, Oman: P-T paths and kinematic interpretation. Tectonophysics 151, 363-86.

Gregory RT, Gray DR and Miller JM (1998) Tectonics of the Arabian margin associated with the emplacement of the Oman margin along the Ibra transect: new evidence from NE Saih Hatat. Tectonics 17, 657-70.

Grobe A, Virgo S, Von Hagke C, Urai JL and Littke R (2018) Multiphase structural evolution of a continental margin during obduction orogeny: insights from the Jebel Akhdar Dome, Oman Mountains. Tectonics 37, 888-913.

Grobe A, Von Hagke C, Littke R, Dunkl I, Wübbeler F, Muchez P and Urai JL (2019) Tectono-thermal evolution of Oman's Mesozoic passive continental margin under the obducting Semail Ophiolite: a case study of Jebel Akhdar, Oman. Solid Earth 10, 149-75.

Guilmette C, Smit MA, Hinsbergen DJJ, Van Gürer D, Corfu F, Charette B, Maffione M, Rabeau O and Savard, D (2018) Forced subduction initiation recorded in the sole and crust of the Semail Ophiolite of Oman. Nature Geoscience 11, 688-95.

Handy MR, Schmid SM, Bousquet R, Kissling E and Bernoulli D (2010) Reconciling plate-tectonic reconstructions of Alpine Tethys with the geological-geophysical record of spreading and subduction in the Alps. Earth-Science Reviews 102, 121-58.

Hansman RJ, Albert R, Gerdes A and Ring, U (2018) Absolute ages of multiple generations of brittle structures by $\mathrm{U}-\mathrm{Pb}$ dating of calcite. Geology 46, 207-10.

Hansman RJ and Ring U (2018) Jabal Hafit anticline (UAE and Oman) formed by décollement folding followed by trishear fault-propagation folding. Journal of Structural Geology 117, 168-85. 
Hansman RJ, Ring U, Thomson SN, Den Brok B and Stübner, K (2017) Late Eocene uplift of the Al Hajar Mountains, Oman, supported by stratigraphy and low-temperature thermochronology. Tectonics 36, 3081-109.

Holland M, Urai JL, Muchez P and Willemse EJM (2009) Evolution of fractures in a highly dynamic thermal, hydraulic, and mechanical system - (I) Field observations in Mesozoic Carbonates, Jabal Shams, Oman Mountains. GeoArabia 14, 57-110.

Homewood P, Allen PA and Williams GD (1986) Dynamics of the Molasse Basin of western Switzerland. In Foreland Basins (eds PA Allen and P Homewood), pp. 199-217. Oxford: Blackwell Publishing Ltd. International Association of Sedimentologists, Special Publication no. 8.

Hourigan JK, Reiners PW and Brandon MT (2005) U-Th zonation-dependent alpha-ejection in (U-Th)/He chronometry. Geochimica et Cosmochimica Acta 69, 3349-65.

Jacobs J, Thomas RJ, Ksienzyk AK and Dunkl, I (2015) Tracking the Oman Ophiolite to the surface: new fission track and (U-Th)/He data from the Aswad and Khor Fakkan Blocks, United Arab Emirates. Tectonophysics 644, 68-80.

Jolivet L, Faccenna C, Agard P, Frizon de Lamotte D, Menant A, Sternai P, Guillocheau F and Polat A (2016) Neo-Tethys geodynamics and mantle convection: from extension to compression in Africa and a conceptual model for obduction 1. Canadian Journal of Earth Sciences 53, 1190-204.

Jones RR, Pearce MA, Jacquemyn C and Watson FE (2016) Robust best-fit planes from geospatial data. Geosphere 12, 196-202.

Ketcham RA, Gautheron C and Tassan-Got L (2011) Accounting for long alpha-particle stopping distances in (U-Th-Sm)/He geochronology: refinement of the baseline case. Geochimica et Cosmochimica Acta $\mathbf{7 5}$, 7779-91

Lacombe O, Lavé J, Roure FM and Vergés J (2007) Thrust Belts and Foreland Basins: From Fold Kinematics to Hydrocarbon Systems. Berlin: Springer Science and Business Media, 492 pp.

Lyon-Caen H and Molnar P (1985) Gravity anomalies, flexure of the Indian plate, and the structure, support and evolution of the Himalaya and Ganga Basin. Tectonics 4, 513-38.

Mann A, Hanna SS, Nolan SC, Mann A and Hanna SS (1990) The postCampanian tectonic evolution of the Central Oman Mountains: tertiary extension of the Eastern Arabian Margin. In The Geology and Tectonics of the Oman Region (eds AHF Robertson, MP Searle and AC Ries), pp. 549-63. Geological Society of London, Special Publication no. 49.

Mattern F and Scharf A (2018) Postobductional extension along and within the Frontal Range of the Eastern Oman Mountains. Journal of Asian Earth Sciences 154, 369-85.

Michard A, Goffé B, Saddiqi O, Oberhänsli R and Wendt AS (1994) Late Cretaceous exhumation of the Oman blueschists and eclogites: a two-stage extensional mechanism. Terra Nova 6, 404-13.

Mitra G and Yonkee WA (1985) Relationship of spaced cleavage to folds and thrusts in the Idaho-Utah-Wyoming thrust belt. Journal of Structural Geology 7, 361-73.

Mosar J (1999) Present-day and future tectonic underplating in the western Swiss Alps: reconciliation of basement/wrench-faulting and décollement folding of the Jura and Molasse basin in the Alpine foreland. Earth and Planetary Science Letters 173, 143-55.

Mount VS, Crawford RIS and Bergman SC (1998) Regional structural style of the Central and Southern Oman Mountains: Jebel Akhdar, Saih Hatat, and the Northern Ghaba Basin. GeoArabia 3, 475-90.

Muñoz JA (1992) Evolution of a continental collision belt: ECORS-Pyrenees crustal balanced cross-section. In Thrust Tectonics (ed. KR McClay), pp. 235-46. Dordrecht: Springer Netherlands.

Murray KE, Orme DA and Reiners PW (2014) Effects of U-Th-rich grain boundary phases on apatite helium ages. Chemical Geology 390 135-51.

Nolan SC, Skelton PW, Clissold BP and Smewing JD (1990) Maastrichtian to early Tertiary stratigraphy and palaeogeography of the Central and Northern Oman Mountains. In The Geology and Tectonics of the Oman Region (eds AHF Robertson, MP Searle and AC Ries), pp. 495-519. Geological Society of London, Special Publication no. 49.
Noweir MA and Alsharhan AS (2000) Structural style and stratigraphy of the Huwayyah anticline: an example of an Al-Ain Tertiary fold, northern Oman Mountains. GeoArabia 5, 387-402.

Ori GG and Friend PF (1984) Sedimentary basins formed and carried piggyback on active thrust sheets. Geology 12, 475-8.

Poupeau G, Saddiqi O, Michard A, Goffe B and Oberhansli R (1998) Late thermal evolution of the Oman Mountains subophitic windows: apatite fisson-track thermochronology. Geology 26, 1139-42.

Rabu D, Nehlig P, Roger J, Béchennec F, Beurrier M, LE Métour J, Bourdillon Jeudy-De-Grissac C, Tegyey M, Chauvel J-J., Cavelier C, Al Azri H, Juteau T, Janjou D, Lemière B, Villey M and Wyns R (1993) Stratigraphy and Structure of the Oman Mountains. Orléans: Bureau de recherches geologiques et minières. Documents du BRGM 221, 300 pp.

Railsback BL and Andrews LM (1995) Tectonic stylolites in the 'undeformed' Cumberland Plateau of southern Tennessee. Journal of Structural Geology 17, 911-15.

Ramsay JG and Huber MI (1987) The Techniques of Modern Structural Geology: Folds and Fractures. London: Academic Press Inc., 700 pp.

Recanati A, Gautheron C, Barbarand J, Missenard Y, Pinna-Jamme R, TassanGot L, Carter A, Douville E, Bordier L, Pagel M and Gallagher K (2017) Helium trapping in apatite damage: insights from (U-Th-Sm)/He dating of different granitoid lithologies. Chemical Geology 470, 116-31.

Ricci Lucchi F (1986) The Oligocene to Recent foreland basins of the northern Apennines = Les bassins d'avant-pays de l'Oligocène à l'Actuel dans les Apennins Nord. In Foreland Basins (eds PA Allen and P Homewood), pp. 105-39. Oxford: Blackwell Publishing Ltd. International Association of Sedimentologists, Special Publication no. 8.

Robertson AHF (1987) Upper Cretaceous Muti Formation: transition of a Mesozoic nate platform to a foreland basin in the Oman Mountains. Sedimentology 34, 1123-42.

Robertson AHF (1988) Late Cretaceous chemical sediments related to a carbonate platform-foreland basin transition in the Oman Mountains. Sedimentary Geology 57, 1-15.

Robertson AHF and Searle MP (1990) The northern Oman Tethyan continental margin: stratigraphy, structure, concepts and controversies. In The Geology and Tectonics of the Oman Region (eds AHF Robertson, MP Searle and AC Ries), pp. 3-25. Geological Society of London, Special Publication no. 49.

Robertson AHF, Searle MP and Ries AC (eds) (1990) The Geology and Tectonics of the Oman Region. Geological Society of London, Special Publication no. 49, 831 pp.

Roure F, Andriessen P, Callot J-P, Faure JL, Ferket H, Gonzales E, Guilhaumou N, Lacombe O, Malandain J, Sassi W, Schneider F, Swennen R and Vilasi N (2010) The use of palaeo-thermo-barometers and coupled thermal, fluid flow and pore-fluid pressure modelling for hydrocarbon and reservoir prediction in fold and thrust belts. In Hydrocarbons in Contractual Belts (eds GP Goffey, J Craig, T Needham and R Scott), pp. 87-114. Geological Society of London, Special Publication no. 348 .

Saddiqi O, Michard A, Goffe B, Poupeau G and Oberhänsli R (2006) Fissiontrack thermochronology of the Oman Mountains continental windows, and current problems of tectonic interpretation. Bulletin de la Société Géologique de France 177, 127-43.

Saura E, Garcia-Castellanos D, Casciello E, Parravano V, Urruela A and Vergés J (2015) Modeling the flexural evolution of the Amiran and Mesopotamian foreland basins of NW Zagros (Iran-Iraq). Tectonics 34, 377-95.

Scharf A, Mattern F and Al-Sadi SS (2016) Kinematics of post-obduction deformation of the Tertiary Ridge at Al-Khod village. SQU Journal for Science 21, 26-40.

Searle MP (2007) Structural geometry, style and timing of deformation in the Hawasina Window, Al Jabal al Akhdar and Saih Hatat culminations, Oman Mountains. GeoArabia 12, 99-130.

Searle MP (2014) Preserving Oman's geological heritage: proposal for establishment of World Heritage Sites, National GeoParks and Sites of Special Scientific Interest (SSSI). In Tectonic Evolution of the Oman Mountains (eds HR Rollinson, MP Searle, IA Abbasi, A Al-Lazki and MH Al Kindi), pp. 9-44. Geological Society of London, Special Publication no. 392 
Searle MP and Ali MY (2009) Structural and tectonic evolution of the Jabal Sumeini - Al Ain - Buraimi region, northern Oman and eastern United Arab Emirates. Geo Arabia (Manama) 14, 115-42.

Searle MP, Cherry AG, Ali MY and Cooper DJW (2014) Tectonics of the Musandam Peninsula and northern Oman Mountains: from ophiolite obduction to continental collision. GeoArabia 19, 135-74.

Searle MP and Cooper DJW (1986) Structure of the Hawasina Window culmination, central Oman Mountains. Transactions of the Royal Society of Edinburgh: Earth Sciences 77, 143-56.

Searle MP and Cox J (2002) Subduction zone metamorphism during formation and emplacement of the Semail ophiolite in the Oman Mountains. Geological Magazine 139, 241-55.

Searle MP, Warren CJ, Waters DJ and Parrish RR (2004) Structural evolution, metamorphism and restoration of the Arabian continental margin, Saih Hatat region, Oman Mountains. Journal of Structural Geology 26, 451-73.

Searle MP, Waters DJ, Martin HN and Rex DC (1994) Structure and metamorphism of blueschist-eclogite facies rocks from the northeastern Oman Mountains. Journal of the Geological Society 151, 555-76.

Seers TD and Hodgetts D (2016) Probabilistic constraints on structural lineament best fit plane precision obtained through numerical analysis. Journal of Structural Geology 82, 37-47.

Storti F, Balsamo F, Clemenzi L, Mozafari M, Al-Kindy MHN, Solum J, Swennen R, Taberner C and Tueckmantel C (2015) Complex fault-fold interactions during the growth of the Jabal Qusaybah anticline at the western tip of the Salakh Arch, Oman. Tectonics 34, 488-509.

Tarapoanca M, Andriessen P, Broto K, Chérel L, Ellouz-Zimmermann N, Faure J-L, Jardin A, Naville C and Roure F (2010) Forward kinematic modelling of a regional transect in the Northern Emirates using geological and apatite fission track age constraints on paleo-burial history. Arabian Journal of Geosciences 3, 395-411.

Tavani S, Arbues P, Snidero M, Carrera N and Muñoz JA (2011) Open Plot Project: an open-source toolkit for 3-D structural data analysis. Solid Earth 2, 53-63.
Tavani S, Corradetti A, de Matteis M, Iannace A, Mazzoli S, Castelluccio A, Spanos D and Parente M (2019) Early-orogenic deformation in the Ionian zone of the Hellenides: effects of slab retreat and arching on syn-orogenic stress evolution. Journal of Structural Geology 124, 168-81.

Tavani S, Storti F, Lacombe O, Corradetti A, Muñoz JA and Mazzoli S (2015) A review of deformation pattern templates in foreland basin systems and fold-and-thrust belts: implications for the state of stress in the frontal regions of thrust wedges. Earth-Science Reviews 141, 82-104.

Van Hinsbergen DJJ, Peters K, Maffione M, Spakman W, Guilmette C, Thieulot C, Plümper O, Gürer D, Brouwer FM, Aldanmaz E and Kaymakci N (2015) Dynamics of intraoceanic subduction initiation: 2. Suprasubduction zone ophiolite formation and metamorphic sole exhumation in context of absolute plate motions. Geochemistry, Geophysics, Geosystems 16, 1771-85.

Virgo S (2015) Aspects of crack-seal vein system evolution. PhD thesis, RWTH Aachen University, Aachen, Germany. Published thesis, 261 pp.

Von Hagke C, Cederbom CE, Oncken O, Stckli DF, Rahn MK and Schlunegger F (2012) Linking the northern Alps with their foreland: the latest exhumation history resolved by low-temperature thermochronology. Tectonics 31, 1-25.

Warburton J, Burnhill TJ, Graham RH and Isaac KP (1990) The evolution of the Oman Mountains Foreland Basin. In The Geology and Tectonics of the Oman Region (eds AFH Robertson, MP Searle and AC Ries), pp. 419-27. Geological Society of London, Special Publication no. 49.

Warren CJ, Parrish RR, Searle MP and Waters DJ (2003) Dating the subduction of the Arabian continental margin beneath the Semail ophiolite, Oman. Geology 31, 889-92.

Weil AB and Yonkee WA (2012) Layer-parallel shortening across the Sevier fold-thrust belt and Laramide foreland of Wyoming: spatial and temporal evolution of a complex geodynamic system. Earth and Planetary Science Letters 357-358, 405-20.

Wübbeler F, Von Hagke C, Grobe A, Nokar K and Urai JL (2015) The latest stage of an obduction orogen: doming of the Jebel Akhdar constrained by structural geology and low-temperature thermochronology. Geotectonic Research 97, 103-5. 